Research Report No. 12/2012

\title{
Community, Enforcement and Justification: The International Law of Intervention in World-Societal Perspective
}

Stefan Kroll

Follow this and additional works at: http:/ / digitalcommons.osgoode.yorku.ca/clpe

\section{Recommended Citation}

Kroll, Stefan, "Community, Enforcement and Justification: The International Law of Intervention in World-Societal Perspective" (2012). Comparative Research in Law \& Political Economy. Research Paper No. 12/2012.

http://digitalcommons.osgoode.yorku.ca/clpe/11 


\section{OSGOODE}

\section{OSGOODE HALL LAW SCHOOL}

Comparative Research in Law \& Political Economy

RESEARCH PAPER SERIES

Research Paper No. 12/2012

Community, Enforcement and Justification - The International Law of Intervention in World-Societal Perspective

Stefan Kroll

\section{Editors:}

Peer Zumbansen (Osgoode Hall Law School, Toronto, Director, Comparative Research in Law and Political Economy) John W. Cioffi (University of California at Riverside)

Leeanne Footman (Osgoode Hall Law School, Toronto, Production Editor)

Comparative Research in Law \& Political Economy 
Osgoode CLPE Research Paper 12/2012

Vol. 08 No. 03 (2012)

\title{
Stefan Kroll
}

\section{Community, Enforcement and Justification - The International Law of Intervention in World-Societal Perspective}

\begin{abstract}
The article discusses the normative integration of the world society by the case of international legal discourses on intervention in the late $19^{\text {th }}$ and early $20^{\text {th }}$ century. Within the framework of a non-interventionist international legal structure, international rights and obligations to intervene form an unlikely case which helps to reveal unexpected degrees of normative integration on the international level. The article combines sociological world society research with insights from international relations theory and comparative constitutionalism. The article discusses three interconnected steps of integration: the emergence of semantics of international community, its legal enforcement and justification. The analysis shows a legalization of international politics with constitutional characteristics. In addition to that, the results contribute to the growing literature on the history of international (humanitarian) intervention and have the potential of diachronic comparison with current intervention situations.
\end{abstract}

Key words: Law and Globalization, World Society, Social Integration, International Community, International Intervention 


\section{Introduction}

The sociolegal research on "Law and Globalization" has two general strands of interest. The legal debate is dominated by studies on the consequences of novel national, transnational and international actor constellations and the legal challenges that follow from this (Schiff Berman, 2005; Sieber, 2010). The sociological literature instead investigates primarily the global diffusion of norms, the puzzle of global-local legal interactions and the emergence of global legal institutions (Boyle and Meyer, 1998; Halliday and Carruthers, 2007; Halliday and Osinsky, 2006; Risse-Kappen, Ropp and Sikkink, 1999).

In this article I address the foundations of the latter literature. Underlying the problem of global-local legal interrelations and the emergence of global legal institutions is the question of the shared normative consciousness of legal actors on the world societal level. The article builds on the sociological tradition which assigns the concept of society from the local on the global scale and considers "the world as a whole as the primordial unit of analysis" (Bergesen 1980). Taking this as a vantage point I study the foundations of the legal integration of this world society.

The paper investigates the consciousness of global normative integration using the international legal theory on the question of intervention in the late $19^{\text {th }}$ and early $20^{\text {th }}$ century as primary data source. These discourses are relevant in the context of international normative integration since they constitute a most unlikely case. Given the predominant normative framework of national independent sovereignty and non-intervention in the $19^{\text {th }}$ century, the article highlights the semantics of international community and elaborates how rights and obligations of intervention were built, enforced and justified on these grounds. 
Doing this, the descriptive parts contribute to the growing literature on the history of international interventions; a literature that is strikingly narrowed to the issue of "Humanitarian Intervention" (Barnett, 2011; Knudsen, 2009; Trim and Simms, 2011). These perspectives are narrowed because the legal theory of international intervention in the $19^{\text {th }}$ century is too complex to discuss the subcategory of humanitarian intervention independently. Furthermore, not only historical sources but also recent debates show that the issue of intervention is not limited to the humanitarian sphere but is also important in light of economic and financial relations as in the recent European debt crisis. This potential for diachronic comparison makes the analysis of $19^{\text {th }}$ century intervention law relevant for the overarching question of global normative consciousness as well as for current debates on the legal conceptualization of interventions (see also Glanville, 2011).

The theoretical puzzle consists in the analysis of the construction of a legal "global consciousness" (Robertson) and the study of how the idea of community was used as a precondition for the establishment of international norms to interfere. A central aim of this article is to carve out "semantics" that urge the community and by this advance the "genesis" of a world society. Rudolf Stichweh argued that the genesis of the world society consists of both a structural integration on the world societal level - trade, division of labor, etc. - and normative expectations in regard to the emergence of integration of the common humanity - semantics of "ius gentium”, „communitas humani generis“, or "Weltbürgerrecht” (Stichweh, 2004). This article elaborates the latter, the semantics of community building in the international legal theory of intervention in the $19^{\text {th }}$ and 20th century, how they were enacted and protected. 
I will refer to classical sociological concepts of community (Durkheim, Parsons, etc.) to argue that the idea of community is the basis of a process of social integration on the international legal level. This turn to classical sociology theory is justified by two aspects. Firstly, since the essential elements of the debate I intend to unfold in this paper lie in these classical writings; and secondly, for in this literature concepts of community and integration were developed which are used in neighbour disciplines in a similar manner. Thus, the introduction of these, in the end, interdisciplinary rather than purely sociological concepts opens the study and its result for a broader academic audience.

The focus is on the construction of global consciousness in legal theory. Thus, the article is based on a qualitative analysis of legal discourses. The study is not limited to textual interpretations alone but analyzes "utterances" with regard to their intended meaning which is embedded in the particular historical contexts (Skinner, 2002: 86-89). In this sense, the study stands methodologically in the tradition of "conceptual history". A central issue that provoked an approach of conceptual history in the 1970s was the puzzle of the interrelation of "experience" and "expectation" in the constitution of history. A related assumption stands at the outset of this study, which is the interrelation of linguistics and social change (Koselleck, 1979). In more concrete terms, the analysis in this article studies texts and their intended meanings to learn about the emergence and developments of social changes. The primary aim is not to gather data which is representative in an empirical sense but rather to carve out argumentative patterns which explain social changes that may be further tested in more comprehensive research settings in the future.

The article uses semantic data to learn about the emergence of shared normative values in the world society. The discussion shows that the international law of intervention was based on a 
consciousness of collectivity of the "international community"; an idea that was introduced as a legal principle in the mid of the $19^{\text {th }}$ century. Building on this idea, individual and collective action was legitimized to protect the security of the community and international legal principles. Within this frame interventions were justified by their motivations (humanitarian, political, economical) but also by its success. In particular the latter suggests to be interpreted as a legalization of international power with constitutional characteristics.

Altogether the article contributes to the debate on the normative integration of the world society by using unaccounted historical data and interlinking the analysis to adjacent debates in transnational legal theory. Out of the historical data I discuss three interrelated steps of integration: the use of semantics of the international community, its legal enforcement and justification. As I will show, in the sociological literature it is a subject of controversy whether social integration is a normative or a functionalist development.

The general argumentative steps, the article presents, can be summarized as follows: Based on the idea of community, international laws that allow intervention into the sphere of an independent sovereign international entity are formulated in international legal texts. Effective enforcement institutions then lift the idea of community beyond the semantic stage. Eventually, justifications are important in the analysis of interventions not only because they reveal the set of shared values behind intervention rights (Finnemore, 1996; Knudsen 2009: 33) but also as a legal category which legitimates the exercising of political power by its motivation and its success. This legalization of power carries constitutional characteristics which in turn furthers the process of international normative integration. 
The article is organized in three sections. The first section sets out the problem of intervention in regard to the fundamental conflict of international order between "national independence" and "international solidarity". In the second section, on the consciousness of collectivity, I discuss how the idea of international community was used in international legal doctrines to justify the interference in national independence and by this advanced the normative integration of the world society. The third section turns to the question of how these doctrines were put into practice and focuses on the enforcement and justification of international intervention laws. It becomes clear, that the international law of intervention went beyond the semantic stage and rather emerged as an enforceable set of legal doctrines with constitutional characteristics. The concluding section summarizes the main theoretical contribution and set out perspectives for future research.

\section{Integration, community and the problem of intervention}

In this section I develop the main problem of intervention, the tension between the legal independence of nation states and their integration into the international legal system. I do this in light of sociological concepts of integration and community, originally rendered by Durkheim and Parsons.

As already mentioned the decision to go back to classical sociological readings is meant to introduce and open the analysis for a more interdisciplinary audience, rather than the specified community of sociological readers. The study of shared norms and values does not only shape the discussion about the world society until today but is also the angle to connect the results to the neighbor fields in political science and legal studies which develop and use these heuristics in a similar sense. 
The notion of integration is a key term in writings on global law. Integration generally describes the participation of an individual, an organization, or a state in trans- or international legal regimes. Though integration is usually conceived as a self evident concept in this context, different usages appear in the legal and sociological literature. The most fundamental discrepancy seems to be that whereas in the legal literature a tradition exist which uses the term of integration to describe an outcome - possibly going back to Rudolph Smend's Integrationslehre (Smend, 1928) - sociological authors emphasize integration as a process which leads to the formation of society. It is this role of integration in the process of society formation which is important in the context of this article.

The social integration of societies is the fundamental subject of sociology. The controversies about the dynamics which drive processes of social integration - solidarity (Durkheim), conflict (Simmel, later Dahrendorf), shared norms and values (Parsons), functional differentiation (Luhmann) etc. - are as old as the discipline itself. This is true also for the different levels of integration - Gemeinschaft and Gesellschaft (Tonnies), social integration and systems integration (Lockwood) - which have to be addressed in an adequate treatment of the issue. In this section I will take from these debates what is essential to motivate the research question of this paper and do not mean to cover the field as a whole.

Generally, the following analysis of social integration has to deal with solidarity and conflict. Solidarity has to be addressed because any right or obligation of intervention is based on the idea of an international community, on the consciousness of common collective interests of international legal actors. The dimension of conflict is pertinent, since the international law of intervention in the end is an instrument (or institution) to order international dispute and 
violence. Thus, both solidarity and conflict are considered decisive factors in the emergence of social integration. This corresponds also with David Lockwood's model of different levels of integration, which emphasizes that both the "social integration" of the actors of a social system and the "system integration" between the parts of a social system have to be addressed to get an adequate perspective on social change (Lockwood, 1964: 244- 245).

With regard to solidarity as a driving factor of social integration I shall refer first of all to Emile Durkheim (see overview by Turner, 1981). In his "The division of labour in society" Durkheim states that it is "internal solidarity" that "causes the unity of organised societies" (Durkheim 1893/1984: 297). As a central notion to explain the internal solidarity of a society throughout the book he uses the term of "collective consciousness" which is defined as "[t]he totality of beliefs and sentiments common to the average members of a society [that] forms a determinate system with a life of its own" (Durkheim, 1893/1984: 38-39). In this regard, the empirical parts of the article show that with view on international integration a central aspect of "collective consciousness" is first of all the awareness of international actors of shared needs and interests: In other words international actors are characterized by a consciousness of collectivity.

Based on this, "laws" and "morals" emerge, the "essential function" of which ", [...], is to be the integrating element in a whole", and which, in consequence "remove from the individual some of his freedom of movement" (Durkheim, 1893/1984: 331). In other words, individuals (or in our context states) which are generally characterized by egoistic motivations on the one hand, on the other hand do care for the existence of collective interests and needs and therefore have an incentive to form a society and sacrifice part of their independence (or sovereignty) as individual (states). 
However, this bears a paradox that Durkheim rendered in the following way and which is a characteristic condition of international interventions as well:

"The question that has been the starting point for our study has been that of the connection between the individual personality and social solidarity. How does it come about that the individual, whilst becoming more autonomous, depends ever more closely upon society? How can he become at the same time more of an individual and yet more linked to society? For it is indisputable that these two movements, however contradictory they appear to be, are carried on in tandem. Such is the nature of the problem that we have set ourselves."'(Durkheim, 1984: $\mathrm{XXX})$

Directly referring to Durkheim and his analysis of "solidarity", Talcott Parsons developed his concept of a "Societal Community" which is fundamentally based on a "mutual identification as common members of a social collectivity". Similar to Durkheim, Parsons identified solidarity "as the central feature of the state of integration of a social system". One factor of this solidarity is a "bindingness" of collective (political) decisions. The acceptance of bindingness, thus, is part of the integrative process and creates in this course also obligations (Parsons, 2007: 56-58). Elsewhere, Parsons concluded generally that "the boundaries of a society tend to coincide with territorial jurisdiction of the highest-order units of political organization" (Parsons, 1961: 46). I will show below, that this indeed lead Parsons to the conclusion that the international system is not a world society, for he considered these conditions as not fulfilled on the international level. However, it is one task of this paper to question this and to investigate were to draw societal boundaries with regard to the international law of intervention.

I now move on to the problem of intervention. In heuristic analogy to the paradox between individualisation and solidarity coined by Durkheim above, the underlying dilemma of any case of international intervention is the tension between the legal independence of nation states and 
their integration into the international legal system. At the same time this is the fundamental issue of international order in general. Legal historians refer in this regard to Gustave RolinJaequemyns, one of the founding members of the Institut de droit international, who in 1876 remarked that the issue of intervention is of greatest importance for the study of international law, since it directly addresses the polarity of national independence and international solidarity (Rolin-Jaequemyns, 1876: 676; Vec, 2010: 141).

National independence is the expression of the principle of sovereignty - a principle which is considered to be the fundamental basis of the international legal system since the Peace of Westphalia in 1648. Even though the empirical importance of sovereignty is qualified from different disciplinary perspectives (Krasner, 1999: 24; Trim, 2011), it still is the standard narrative in studies on the intellectual history of international law and international relations (Philpott, 2001). I show in the following that the role of the principle of sovereignty is to be questioned not only in practical but also in conceptual terms. By mid of the 19th century ideas of international community emerged as legal concepts. As yet, these concepts have received relatively little scholarly attention in the debate on the emergence of international community (exceptions are Koskenniemi, 2001: 32; Vec, 2006: 48-74).

The following sections describe how the abstract idea of international community was transformed into legal doctrines and legal practices respectively. From the beginning, the international community was more than just a normative goal. The concepts of international community were regarded as a "philosophy of international law" from the perspective of $19^{\text {th }}$ century actors. This philosophy aimed at laying the foundations of the legal system independently from applicable law (Vec, 2006: 52) these concepts were actually presented as international laws. 


\section{The consciousness of collectivity}

The basis of the international law of intervention is the idea of an international community of states. The analysis of legal discourses in this section shows that this consciousness of collectivity is the key heuristic for the establishment and the justification of intervention norms. The right to interfere, as part of a legal system that is based on the fundamental principle of sovereignty, does not work without a sense of collectivity. Based on the idea of the community, force against independent states is justified in cases where the security and the normative values of the international community are at stake.

It follows from this, that the idea of an integrated international community is the central rationale to conceptualize norms of intervention. Based on the consciousness that all states have common needs as they have individual interests, legal doctrines are created which justify the interference into the affairs of other international legal entities. Only against this background the right - and sometimes even the obligation - to interfere into the sovereignty of another international legal actor appears as a necessity.

Let me illustrate this with representative legal discourses from the late $19^{\text {th }}$ and early $20^{\text {th }}$ century. In 1879, the German lawyer Hermann Strauch published a study on the matter of intervention which Ellery C. Stowell described later as "probably the most complete and most rigidly scientific discussion on intervention in any language." Stowell concluded that "[f]or Strauch intervention is a right of the community of states to prevent any abuse of independence which endangers the common security." (Stowell, 1921: 533) This conclusion was published two years after the end of the First World War and the foundation of the League of Nations at the 
Paris Peace Conference. One could argue that these facts explain Stowell's enthusiasm about Herman Strauch's community inspired thoughts.

However, Strauch's writings indeed represent a widespread perspective in the international law literature of that time. Strauch introduced his study not as a new intervention theory but as a conclusion of the existing legal literature that takes into account also intervention practices (Strauch, 1879: 1). He generally differentiated between intervention rights and intervention duties. With regard to the intervention rights, Strauch argued that it is based on the legal community of peoples, the "Rechtsgenossenschaft der Völker". The right of intervention would be a necessity for the members of this community and its aim was to abolish any form of threat for the common interests (Strauch, 1879: 3-4).

This argument followed a natural law-logic. Nikolaos Tsagourias concluded with regard to the history of humanitarian intervention, "[b]ecause humanitarian intervention is prima facie an assault on state sovereignty it is legitimized by being integrated into a natural law theory which envisages an enveloping human society". Tsagourias referred to Antoine Rougier's important essay "La théorie de l'intervention d'humanité" (1910), in which Rougier argued that "people live in a triple social organisation: national, international and the société humaine regulated by the droit human" (Tsagourias, 2000: 14).

However, even though the droit humain was not confirmed by treaties and state practices, these sources reveal the deep conviction of the international lawyers of the 19th century that an inseparable part of independent sovereignty was responsibility, namely the responsibility to protect not only individual rights of a state, but also the international community and the international legal order in general. This aspect was highlighted recently by Luke Glanville who 
emphasized the similarity of that logic to the concept of a responsibility to protect today (Glanville, 2011).

With regard to the question what higher principle may justify a break of the noninterventions norm, another important commentator on the international law of intervention answered: "the interests of humanity" and the "sacred human rights". This conclusion is published in the article on intervention in the Deutsches Staats-Wörterbuch edited by Johann Caspar Bluntschli and Karl Brater. In Vol. 5, 1860, Albert F. Berner wrote on the "Intervention (völkerrechtliche)". Legal historian commentators emphasize the broad bibliographical basis of this encyclopedia entry and therefore underline the significance of this synthesis for the intervention literature in the $19^{\text {th }}$ century (Vec, 2010: 136).

Berner explicitly stressed the general principle of non-intervention (Stowell, 1921: 472) as well as the lack of a common state practice of intervention but he also presented exceptions from this rule (Berner, 1860: 350). Beside legitimate reason of states to intervene in another state when their own rights and interest had been infringed - a case Berner actually did not consider as intervention but as war in the classical sense - he mentioned that violations of humanitarian interests and in particular human rights would justify international intervention. Furthermore, Berner argued that interventions are legitimate if their aim is to protect the status quo of the European state system (Berner, 1860: 353). Even though the stability of the European system formulates the value of community just as a regional value - in a way that is quite typical for in particular German international lawyers in the 19th century (Fisch, 1992) - it fits into the above depicted heuristic that first a sense of community has to established before a right is to be invoked. 
The pattern of an international intervention law that is based on a solidary international state system is confirmed also by other authors with reference to other sources of the $19^{\text {th }}$ century international legal theory (Knudsen, 2009; Koskenniemi, 2001: 341). The degrees of commitment to the international community might vary, yet it is always a higher sense of community on which intervention laws are based. However, it is necessary to deepen the perspective in regard to the origins of this higher principle, the idea of community, in the 19th century since most of the research on intervention fails to do so. Most of them do not go into detail, though. They do not talk about where that principle of an "idea of community" originated from in the $19^{\text {th }}$ century.

So what is the origin of the idea of community to which all those authors refer to justify the international law of intervention? At first glance, we find semantics of the community throughout the intellectual history of international law and beyond (Stichweh, 2004). For the history of international law in the 19th century, however, one contribution is of significant importance.

In 1860, Robert von Mohl published his essay on the "Die Pflege der internationalen Gemeinschaft als Aufgabe des Völkerrechts" (Mohl, 1860). The treatise built on a debate which was introduced earlier by Bulmerinq, von Gagern and Kaltenborn von Stauchau and was attributed to the scientification and professionalization of the international law discipline (Mohl, 1860: 579). Thus, it was a contribution to a debate of German writers, which, however, was deeply influential even beyond the German speaking world (Koskenniemi, 2010).

Robert von Mohl presented his argument on the international community explicitly as a legal concept, based on legal reasoning (Mohl, 1860: 586). Two principles are at the center of his international legal theory: Firstly, the independent sovereignty of states; and secondly, the 
international community. According to Mohl, the principle of sovereignty would constitute just one step in the evolution of international law while the formation of the international community would be its final purpose (Mohl, 1860: 585-586). By this argument, Mohl exceeded the predominant positivist rationale of $19^{\text {th }}$ century international law. In fact, he embedded the universal idea of international community, which was already discussed in the natural law tradition (one just has to think of Kant), within the recent methodological discussion in positivist international legal theory. Firstly, he qualified the status of sovereignty, and secondly, he accepted a philosophical reason as rationale for the formation of legal normativity.

This section showed that the international law of intervention in the $19^{\text {th }}$ and early $20^{\text {th }}$ century was based on the idea of international community. Taking the collective needs of the community as a vantage point, the right to intervene was presented as a necessity of the international legal system. This necessity had the potential to overrule individual interests of sovereign actors within the international system. Thus, the semantics of community in the international legal literature of intervention suggest an international normative integration that goes beyond an image of international legal relations in the $19^{\text {th }}$ and early $20^{\text {th }}$ century which usually conceive international law as a positivist system that is based on the principle of independent westphalian sovereignty only. Though the findings in the semantic analysis of small number of theoretical texts cannot claim to be representative in an empirical sense, it means an important explorative input for further comparative studies on the nature of intervention laws and the normative integration of the world society. 


\section{Law, force and justification -The legalization of effective power}

I turn now to the question whether the idea of community in the international legal literature was merely a normative symbol or even an enforceable international law. I showed in the preceding section that the idea of the international community was the foundation of international intervention law. However, did this law also provide instruments and mechanisms to enforce interventionist rights? This is an important question in the international legal context since international laws, though binding in principle, were not subject to central enforcement institutions. Therefore, to understand the international ordering process as a whole, one has to ask under what conditions and by which means international norms were enforced. This is not only a question of practice of international law. In this section I focus on the conceptualization of law enforcement in the international legal literature on intervention. In the following I show that the international law of intervention was characterized by effective enforcement institutions and thus was not a law without force.

To unfold this point, I start, again, with the question of social integration. Talcott Parsons remarked in the 1960s that the consciousness of collectivity alone does not form an integrated society. He emphasized the importance of an ordering normative frame as "core of the society, as a system, [...]" (Parsons, 1966: 10). World society theorists' pointed out, that Parsons had doubts whether the international system in the 1960s fulfilled the conditions to be qualified as a "world society". According to Parsons, the international system would lack a binding normative structure since the international legal system would not provide effective institutions to enforce the international law (Greve and Heintz, 2005: 94). 
This observation by Parsons is analogue to the classical criticisms of international law pessimists ("Völkerrechtsleugner") who are constant companions of international legal developments throughout the history of international law (Walz, 1930). The main argument of international law pessimists is that, based on the observation of international law's lack of centrality, the status of international law as a legal order is contested. However, throughout the history of international law this has been invalidated by at least two argumentative strategies:

Firstly, pleas that stress the fact that international law was followed by its addressees empirically - "almost all of the time" (Henkin, 1979: 47). Henkin's famous phrase is usually used to point out that the international legal order, though weak in terms of central force, after all fulfilled its general function as a legal order which is to guarantee the reliability of expectations (Luhmann, 1993: 132). However, it was up to sociolegal researchers to explain this empirical observation. In this context, constructivist and rationalist theories of international relations became predominant (for an overview see Brunnée, 2006).

Secondly, approaches which argue that international law does not entirely lack institutionalized forms of enforcement (Grosch, 1912). In this context, the international law of intervention is highly relevant. In the following I will refer to this latter strategy, the conceptualization of force to enact and protect the international community as part of the international legal system, to show that the idea of community exceeded the purely semantic realm.

The focus is on collective forms of force since bi-lateral self-help can be understood, as Albert F. Berner pointed out above, as war rather than intervention in the name of the community. Furthermore, I shall leave aside issues of invited intervention for these form another 
special case, which is not of relevance for the question of independence and solidarity which lies at the core of this article. Instead I focus on what Herman Strauch has described as the "classical case of intervention": The intervention to save the common security that is performed by a coalition of states and/or organizations. This is the case of intervention which bears the problem of justification in regard to the principle of sovereignty.

Above, I set out that international laws of intervention aimed at preventing or healing violations of international laws, conventions, and expectations which protect the international community. In this context forms of collective intervention are of critical importance; not least because of the symbolic dimension. The international law of intervention shows that international law in its history was not only a self-help system but also produced mechanism of collective intervention. Thus, comments which argue that "historically, enforcement of international law was bilateral" (Brunnée, 2006: 3) have a weak empirical basis. The international law of intervention was not a self-help system alone but also produced mechanism of collective force.

Friedrich Heinrich Geffcken argued in his 1887 treatise on "The Right of Intervention" that in case international law is violated every state has the right to use force to enact international legal norms (Geffcken, 1887: 6-7). Geffcken continued with outlining the risk of arbitrary uses of these rights by single and powerful states. He also discussed the question when a reason for an intervention has ceased to exist, in other words when a threat to the community and international law has been fathered. In this context, Geffcken argued that the best mechanism to ensure the commensuration of intervention measures is the collective intervention of several powers that monitor each other (Geffcken, 1887: 5-6). 
All this shows that the international community was not merely an abstract philosophical goal, a symbol of some progressive international legal thinkers, but rather was empowered by instruments of collective intervention which were anchored in the international legal system. Thus, the international law of intervention, and with it the idea of community, went beyond the semantic stage. It formed a field were even force is legitimized to protect the interests of the community and the international legal system. This also means that international law in fact does provide effective enforcement mechanisms which have to be taken into account when discussing the legal character of the international legal system.

However, the field of intervention law is even more complex. International interventions can be legally justified even if a right to intervene is not acknowledged. This paradox is a key characteristic of the international law of intervention. Lassa Oppenheim, the author of one of the most influential international law treatises of the beginning $20^{\text {th }}$ century, distinguished summarized that there is a general distinction of two kinds of legitimate interventions. The one being interventions by right and the other one being interventions which are not rightful but admissible. Admissible interventions are, beside interventions for self-preservation, those to protect the balance of power and those in the interest of humanity. Those interventions are not interventions by right, which means that a state has no duty to suffer the intervention without self-defense. However, since they are based on legitimate reasons, there are excusable (Oppenheim, 2005: 277ff).

Interventions to protect the Balance of Power occurred in the $19^{\text {th }}$ century for example in the context of international financial relations (Heimbeck, 2011). Even though the Balance of Power was not acknowledged as a legal principle (Vec, 2011) its importance for the common order 
served as a justification for collective intervention (Oppenheim, 2005: 229). The intervention in the interest of humanitarian grounds was frequently discussed as well. Lassa Oppenheim imagined a right of intervention in the name of humanity for the future, under the condition that they were exercised in the form of collective intervention (Oppenheim, 2005: 229).

Oppenheim based his perspective mainly on the influential chapters on intervention by William E. Hall, who, though generally seeing legitimate cases for intervention, was reluctant to confirm a legal right of humanitarian intervention. However, even Hall argued in the 1880s that interventions against immoral acts are justified "when authorized [...] by the whole body of civilized states accustomed to act together for common purposes" (Hall, 1880: 247). This is also confirmed in Henry Wheaton's famous "Elements of international law" which discusses several historical cases of intervention, inter alia those of a coalition of powers in the name of humanity (Wheaton, 1836: 125).

With regard to the justification of international interventions some authors go even further. According to them interventions are not justified by the underlying motivation (moral, political, economical) alone, but also by outcome. Several commentators of the early $20^{\text {th }}$ century highlight that international interventions are simply justified by success (Vincent, 1974: 282; Winfield, 1924: 150). But what is the conceptual reason behind justifications by success which makes an international intervention legally legitimate? Martti Koskenniemi showed that Carl Schmitt presented an argument according to which successful interventions are an "act of effective power and therefore law" and as such "even a kind of constitutional act" (Koskenniemi, 2001: 480; Schmitt, 1995: 605). Schmitt draws this argument obviously from his "Concept of the Political" in which any legal act in the end is based on a political decision (Schmitt, 2007). 
As we saw, the enforcement and justification of the international law of intervention showed that the idea of community transcends the semantic sphere. In the contrary, it was provided with force as long as force was used on legitimate reasons. Thus, this legalization of international power seems to suggest speaking of a constitutional development beyond the national frame. However, this legalization of force and power opened the field for misuses of interventionist rights. The idea of community was a central narrative of justification of asymmetric international relations, dominance and violence in the $19^{\text {th }}$ century and today. So does this fit to the observation of international constitutionalism found by Schmitt and emphasized by Martti Koskenniemi?

Sociolegal researchers emphasize a "Constitutionalism in World Society" with regard to the "post-national" (Habermas) society (Brunkhorst, 2010; Zumbansen, 2012). However, if we understand the notion of constitution in its historical genesis, the aspect of the legalization of political power is not enough to qualify a certain state as constitutional. Dieter Grimm argued that this "existed long before the constitution emerged" (Grimm, 2010: 5). The main "achievement" of the constitution, said Grimm with a reference on Luhmann, was that "it rules out any absolute or arbitrary power of men over men" (Grimm, 2010: 10).

Taking this historical understanding of constitution as a vantage point, leads to the conclusion that the international law of intervention has constitutional characteristics, namely the legalization of power in the name of a community, but since it is not ruled out in way that avoids arbitrary use of it, the usage of the term should be further reflected. Grimm concluded that constitution "can not be reconstructed on the international level", and this has to be discussed 
further (Grimm, 2010: 3). The analytical setting of this paper is, however, too narrow to address this issue adequately.

\section{Conclusion}

I conclude by briefly discussing the main theoretical results and their potential implications for future research.

The paper set out the idea of an international community as the basis of a right of intervention in the international legal literature of the late $19^{\text {th }}$ and early $20^{\text {th }}$ century. Furthermore, it showed that these rights were enacted by effective enforcement institutions. These enforcement institutions of collective action represent a form of legalized international power which entails constitutional characteristics. Thus, the paper suggests that the degree of international normative integration is deeper than international law pessimists have believed throughout the intellectual history of international law. To what extend this had an influence on state actors and the practice of international law, of course has to be investigated in further studies. However, the paper suggests that in particular the idea of community and its legal enactment is not a post-World War II phenomenon but has its roots, in international legal theory, in the beginning of the $19^{\text {th }}$ century. However, this system of legalized international power was always vulnerable to abuse. In an environment of asymmetric international relations it was an instrument to strengthen the dominance of particular international actors.

Generally, it is striking how this pattern looks like the situation we face today; the recent European debt crisis with the international intervention in Greece or the military interventions in Middle Eastern countries. Even though the principle of independent sovereignty is highlighted in all these cases, the global and regional communities insist on their right to intervene to secure the 
common interest. Motivations are humanitarian, economical, and political and justifications are laid out by right or by success. Thus, for the analysis of recent interventionist practices it is necessary to take into account that international interventions have a long history. Their theoretical context is broader than just the case of humanitarian intervention. Concepts, like the independent sovereignty of nation states have to be understood in the context of their historical genesis to see that the "responsibility to protect" for example was understood as an inseparable part of this sovereignty.

A further step in the study of the normative integration in the world society is to deepen the research with regard to the constitutional character of inter- and transnational legal regimes. The legalization of political power has to be accompanied by mechanisms that help restrain arbitrary usages of this power. This is the point where the international law of intervention failed empirically. In the context of world society theory, the article has identified analytical indicators which have the potential to be further developed to a more general model of the question of international normative integration. 


\section{Bibliography}

Barnett, Michael (2011) Empire of humanity: A history of humanitarianism. Ithaca and London: Cornell University Press.

Bergesen, Albert (1980) From utilitarism to globology: The shift from the individual to the world as a whole as the primordial unit of analysis. In: Albert Bergesen (ed) Studies of the modern world-system. New York: Academic Press, 1-12.

Berner, Albert Friedrich (1860) Intervention (völkerrechtliche). Deutsches Staats-Wörterbuch. Stuttgart and Leipzig, 341-354.

Boyle, Elizabeth Heger and John W. Meyer (1998) Modern law as secularized and global model: implications for the sociology of law. Soziale Welt 49: 113-132.

Brunkhorst, Hauke (2010) Constitutionalism and democracy in the world society. In: Petra Dobner and Martin Loughlin (ed) The twilight of constitutionalism? Oxford: Oxford University Press, 179-198.

Brunnée, Jutta (2006) Enforcement mechanisms in international law and international environmental law. In: UIrich Beyerlin et al (ed) Ensuring compliance with multilateral environmental agreements: A dialogue between practitioners and academia. Leiden: Martinus Nijhoff Publishers, 1-24.

Durkheim, Emile (1984) The division of labour in society. London: Macmillan Publishers.

Finnemore, M. (1996). National interests in international society. New York: Cornell University Press.

Fisch, Jörg (1992) Zivilisation, Kultur. In: Otto Brunner, Werner Conze, Reinhart Koselleck (ed) Geschichtliche Grundbegriffe. Historisches Lexikon zur politisch-sozialen Sprache in Deutschland, Bd. 7. Stuttgart: Klett-Cotta, 679-774.

Geffcken, Friedrich Heinrich (1887) Das Recht der Intervention. Hamburg: Verlag von I. F. Richter.

Glanville, Luke (2011) Ellery Stowell and the enduring dilemmas of humanitarian intervention. International Studies Review 13: 241-258.

Greve, Jens and Bettina Heintz (2005) Die “Entdeckung” der Weltgesellschaft. Entstehung und Grenzen der Weltgesellschaftstheorie [The "discovery" of world society. Emergence and limits of the theory of world society]. Zeitschrift für Soziologie (Sonderheft Weltgesellschaft): 89-119. 
Grimm, Dieter (2010) The achievement of constitutionalism and its prospects in a changed world. In: Petra Dobner and Martin Loughlin (ed) The twilight of constitutionalism? Oxford: Oxford University Press, 1-24.

Grosch G et al. (1912) Der Zwang im Völkerrecht, mit besonderer Berücksichtigung des völkerrechtlichen Vertragsrecht: ein Beitrag zur Dogmatik des Völkerrechts. Breslau: M. \& H. Marcus.

Halliday, Terence C. and Bruce G. Carruthers (2007) The recursivity of law: Global norm making and national lawmaking in the globalization of corporate insolvency regimes. American Journal of Sociology 112(4): 1135-1202.

Halliday, Terence C. and Pavel Osinsky (2006) Globalization of law. Annual Review of Sociology 32: 447-470.

Hall, William Edward (1880) International law. Clarendon press.

Heimbeck, Lea (2011) Das Gleichgewicht wahren. Frankfurter Allgemeine Zeitung, 22. Dezember: 8.

Henkin, Louis (1979) How nations behave: law and foreign policy. New York: Columbia University Press.

Knudsen, Tonny Brems (2009) The history of humanitarian intervention: the rule or the exception? paper presented at the 50th Annual Convention of the International Studies Association: Exploring the past - anticipating the future. New York, 1-39. Available at: http://zunia.org/uploads/media/knowledge/isa09_proceeding_378011262835777.pdf.

Koselleck, Reinhart (1979) Vergangene Zukunft. Zur Semantik geschichtlicher Zeiten. Frankfurt: Suhrkamp.

Koskenniemi, Martti (2001) The gentle civilizer of nations: the rise and fall of international law, 1870-1960. New York: Cambridge University Press.

Koskenniemi, Martti (2010) Between coordination and constitution: International law as German discipline. Redescriptions. Yearbook of Political Thought and Conceptual History 14.

Krasner, Stephen D. (1999) Sovereignty: organized hypocrisy. Princeton: Princeton University Press. 
Lockwood, David (1964) Social integration and system integration. In: George K. Zollschan and Walter Hirsch (ed.) Explorations in social change. New York: Houghton and Mifflin, 244-257.

Luhmann, Niklas (1993) Das Recht der Gesellschaft. Frankfurt: Suhrkamp.

Mohl, Robert von (1860) Die Pflege der internationalen Gemeinschaft als Aufgabe des Völkerrechts. In: Robert von Mohl (ed) Staatsrecht, Völkerrecht und Politik. Erster Band. Staatsrecht und Völkerrecht. Tübingen: Laupp\&Siebeck, 579-636.

Oppenheim (2005) International law: A treatise. New Jersey: The Lawbook Exchange, Ltd. Parsons, Talcott (1961) The integration of societies as collectivities. In: Talcott Parsons et al. (ed) Theories of society. Foundations of modern sociological theory. New York: The Free Press of Glencoe: 46-47.

Parsons, Talcott (1966) Societies. Evolutionary and comparative perspectives. New Jersey: Prentice-Hall.

Parsons, Talcott (2007) The societal community and its environments. In: Giuseppe Sciortino (ed) American society. A theory of the social community. Boulder: Paradigm Publishers: 54-89.

Philpott, Daniel (2001) Revolutions in sovereignty: how ideas shaped modern international relations. Princeton: Princeton University Press.

Risse-Kappen Thomas, Ropp, Stephen C. and Sikkink, Kathryn (ed) (1999) The Power of human rights: international norms and domestic change. Cambridge: Cambridge University Press.

Schiff Berman, Paul (2005) From international law to law and globalization. Columbia Journal of Transnational Law 43: 485-556.

Schmitt, Carl (1995) Die Ordnung der Welt nach dem zweiten Weltkrieg. In: Guenter Maschke (ed) Staat, Grossraum, Nomos. Arbeiten aus den Jahren 1916-1969. Berlin: Duncker \& Humblot, 592-618.

Schmitt, Carl (2007) The concept of the political. Chicago: University of Chicago Press.

Sieber, Ulrich (2010) Legal order in a global world - the development of a fragmented system of national, international, and private norms. In: Bogdandy, Armin von and Rüdiger Wolfrum (ed) Max Planck Yearbook of United Nations Law. London and Boston: Brill, $1-50$. 
Skinner, Quentin (2002) Meaning and understanding in the history of ideas. In: Quentin Skinner Visions of politics. Volume 1: Regarding Method. Cambridge: Cambridge University Press, 57-89.

Smend, Rudolf (1928) Verfassung und Verfassungsrecht. Berlin: Duncker \& Humblot.

Stichweh, Rudolf (2004) Der Zusammenhalt der Weltgesellschaft: Nicht-normative Integrationstheorien in der Soziologie. In: Jens Beckert, Julia Eckert, Martin Kohli, Wolfgang Streeck (ed) Transnationale Solidarität. Chancen und Grenzen. Frankfurt: Campus, 236-245.

Stowell, Ellery C. (1921) Intervention in international law. Washington, D.C: J. Bryne.

Strauch, Hermann (1879) Zur Interventions-Lehre. Eine völkerrechtliche Studie. Heidelberg: Carl Winter's Universitätsbuchhandlung.

Trim, D. J. B. (2011) Conclusion: Humanitarian intervention in historical perspective. In: D. J.

B. Trim and Brendan Simms (ed) Humanitarian Intervention: A history. Cambridge: Cambridge University Press, 381-401.

Trim, D. J. B.; Simms, Brendan (2011) Towards a history of humanitarian intervention. In: D. J. B. Trim and Brendan Simms (ed) Humanitarian Intervention: A history. Cambridge: Cambridge University Press, 1-24.

Tsagourias, Nikolaos K. (2000) Jurisprudence of international law: the humanitarian dimension. Manchester: Manchester University Press.

Turner, Jonathan H. (1981) Emile Durkheim's theory of integration in differentiated social systems. The Pacific Sociological Review 24 (4): 379-391.

Vec, Miloš (2006) Recht und Normierung in der Industriellen Revolution: Neue Strukturen der Normsetzung in Völkerrecht, staatlicher Gesetzgebung und gesellschaftlicher Selbstnormierung. Frankfurt: Vittorio Klostermann.

Vec, Miloš (2010) Intervention/Nichtintervention: Verrechtlichung der Politik und Politisierung des Völkerrechts im 19. Jahrhundert. In: Ulrich von Lappenküper and Reiner Marcowitz (ed) Macht und Recht: Völkerrecht in den internationalen Beziehungen. Paderborn: Ferdinand Schöningh, 135-160. 
Vec, Miloš (2011) De-juridifying "Balance of Power" - A principle in 19th century international legal doctrine. Conference Paper No. 5/2011. Paper presented at the European Society of International Law Conference Paper Series. Tallinn Research Forum, 26-28 May 2011, 1-15. Available at: http://ssrn.com/abstract=1968667.

Vincent, R. J. (1974) Nonintervention and international order. Princeton: Princeton University Press.

Wheaton, Henry (1836) Elements of international law: with a sketch of the history of the science. London: B. Fellowes.

Winfield, P. H. (1924) The grounds of intervention in international law. British Journal of International Law 5: 149-162.

Zumbansen, Peer (2012) Comparative, global and transnational constitutionalism: The emergence of a transnational legal-pluralist order. Global Constitutionalism 1:1, 16-52 